\title{
The Influence of Paternalistic Leadership on the Creative Behavior of Knowledge Workers-Based on the Perspective of Psychological Contractual Perception
}

\author{
Yashu Wu \\ School of Management, Jinan University, Guangzhou, China \\ Email: 2538984320@qq.com
}

How to cite this paper: Wu, Y.S. (2018) The Influence of Paternalistic Leadership on the Creative Behavior of Knowledge Workers-Based on the Perspective of Psychological Contractual Perception. Open Journal of Business and Management, 6, 478-487.

https://doi.org/10.4236/ojbm.2018.62036

Received: March 26, 2018

Accepted: April 27, 2018

Published: April 30, 2018

Copyright $\odot 2018$ by author and Scientific Research Publishing Inc. This work is licensed under the Creative Commons Attribution International License (CC BY 4.0).

http://creativecommons.org/licenses/by/4.0/

(c) (i) Open Access

\begin{abstract}
Employee innovation is the foundation of enterprise innovation. Each knowledge worker should be an innovation unit. This reminds managers that they need to examine their own behaviors and methods in the process of organization and management from the perspective of employees. This study is based on the perspective of social exchange theory. Through the combination of interviews and questionnaire surveys, we have referenced domestic and international scales, and analyzed the paternalistic leadership style, psychological contractual awareness, and employee innovation behavior using statistical methods such as correlation analysis and regression analysis. The relationship between paternalistic leadership and the employee's innovative behavior was discussed. The results of this study show that: 1) In the unidimensional analysis, there is a positive relationship among benevolent leadership in paternalistic leadership, psychological and psychological perception, and employee innovation behavior; 2) Authoritarian leadership and psychological contract perception, there is a negative correlation between employee innovation behaviors; 3) There is a significant positive relationship between psychological contract perception and employee innovation behavior.
\end{abstract}

\section{Keywords}

Paternalistic Leadership, Psychological Contract Perception, Employees' Innovative Behavior

\section{Introduction}

Innovation has become the main theme of the developing times. Governments at all levels and all enterprises and institutions are focusing on innovation. As the 
source of innovation, employees naturally become the core of the management and service of the government and enterprises. In recent years, all provinces and cities across the country have issued relevant documents or policies supporting independent innovation, and they are vigorously promoting independent innovation. Due to the attention of the business community, the research on the innovative behavior of knowledge workers in the theoretical community has become increasingly popular. Current research shows that the leadership ability played an important role in the success of the company. It is particularly important for the company that the employee as the direct subordinate of the leader, the executive of the enterprise management, and the individual employee's innovation behavior. The relationship between leaders and employees is very important. The relationship between employees and leaders directly affects the performance of employees. The better the relationship between the leadership and the employees, the better the performances of the employees; and the poorer the relationship between the leaders and the employees, the worser the employees' behavior.

The results of Mather et al. show that Indian employees can not agree more about "paternalistic leadership behavior" and that this behavior is common in both public and private companies. Martinez found that Mexicans are very much in line with the hierarchy, and pay attention to the maintenance of family relationships. Paternal leadership behavior is very effective in such an environment. Martinez and Dorfman found that in Turkey's corporate researches, employees and business managers formed a warm working atmosphere. This kind of warm working atmosphere is very similar to the family environment. Referring to the concept of innovative behavior given by Kleysen \& Street [1], this study defines the innovative behavior of employees as follows: employees introduce and apply all the personal behaviors that are conducive to organizational development. Rousseau and Parks [2] found empirical researches that although there are great individualities and specificities in psychological contract, they can be basically classified into two types: transactional psychological contract and relational psychological contract.

\section{Conception Model}

\subsection{Paternalistic Leadership and Psychological Contract Perception}

Leadership behavior is an antecedent variable of psychological contract, with local characteristics of leadership theory-paternalistic leadership will inevitably have an important impact on employees' psychological perception contract.[3] Due to the peculiarities of Chinese people, the influence of paternalistic leadership on the psychological empowerment of employees is also two-sided: On the one hand, authoritative leaders emphasize the authority of the individual leaders, strictly control the subordinates, and even suppress subordinates' ability to promote employees' sense of self-efficacy. It has a negative impact on psychological contract perception of subordinates; on the other hand, leaders also show 
concern for their subordinates, individual care and maintenance of face, employees expressed gratitude to leaders, and will work hard to reward the benefits of leaders, and the leader's lead by example and behavior that has been promoted by the leader will encourage subordinates to identify and follow suit, improve the enthusiasm and initiative of subordinates' work, and increase the awareness of subordinates' work significance and work influence [4]. At the same time, with the continuous accumulation of experience, subordinates' It is believed that their own abilities have been improved. Benevolent leadership and the leaders of virtues have a positive influence on employees' psychological contractual awareness. Authoritarian behaviors have a negative impact on employees' psychological contractual perception [5].

H1: Benevolent leadership has a positive influence on psychological contract perception

H2: Moral leadership has a positive impact on psychological contract perception

H3: Majestic leadership has a negative impact on psychological contract perception

\subsection{The Relationship between Paternalistic Leadership and Employee Innovation}

Majestic leadership has a negative interaction effect on subordinates' reactions. This conclusion is also true for employees' innovation [6]. In a Chinese society that values human relationships and relationships, when upright and selfless superiors are assisted by high-minded leadership methods, subordinates will feel impersonal, have a sense of shame, and feel that leaders do not trust them, resulting in negative emotions. Creativity research shows that under negative emotions, individuals are more likely to make negative feedback on the opinions of others and are unwilling to disclose themselves. In the Chinese society advocating the Confucian virtue of virtue, Benevolent Leadership views employees as a family, provides them with encouragement, assistance and guidance, creates a good working atmosphere, and makes decisions that are conducive to promoting management innovation [7]. Secondly, moral leadership distinguishes between the public and the private, and can fairly execute the decision-making process so that employees can feel procedural fairness and promote their commitment to decision-making. It can be inferred that the benevolent leadership and ethical leadership behavior of paternalistic leadership promote the creative thinking and behavior of employees [8].

H4: Benevolent leadership has a positive effect on employees' innovation

H5: Moral leadership has a positive effect on employees' innovation

H6: Majestic leadership has a negative impact on employees' innovation

\subsection{Psychological Contract Perception and Employee Innovation Behavior}

Williams [9] and other studies have shown that the satisfaction degree of psy- 
chological contract is positively correlated with the employee's role performance and employee organizational citizenship behavior. Robinson found that there is a negative correlation between psychological contract violations and organizational citizenship behaviors and internal performance; Turnley and Feldman [10] found that psychological contract violations lead to low intra-bureau performance and civic behavior; Yin Jielin and Xu Wei used empirical evidence found Relational psychological contracts are negatively related to organizational citizenship behaviors that point to organizations. Balanced psychological contracts are related to organizational citizenship behaviors that point to organizations.

H7: Psychological contract perception has a positive effect on employee innovation behavior

\subsection{The Conceptual Model of This Article}

As discussed above, the paternalistic leadership and employee innovative behavior and psychological contract, the relationship between the perception of paternalistic leadership have a direct bearing on employee innovative behavior, psychological contract perception can also indirectly affect the relationship between the two.

\section{Analysis Process and Results}

\subsection{Sample and Variable Selection}

The questionnaire measurement scale used in this study is mainly the following three variables: paternalistic leadership (as showed in the Table A1, including three dimensions: benevolence leadership, moral leadership, authoritarian leadership), psychological contract perception (as showed in the Table A2, including three dimensions: transaction responsibility perception, sense of responsibility, relationship responsibility awareness), and employee innovation behavior (as showed in the Table A3, including two dimensions: The creation of innovative behavior and the implementation of innovative behavior). Combined with actual and surveyable resources, the target recovery questionnaire was determined to be 250 copies. This study used four methods to conduct questionnaires: 1) issued questionnaires for specific groups in provincial libraries; 2) fill out the questionnaire from entrusted friends. Finally 196 questionnaires were collected and the recovery rate was $78.4 \%$.

\section{Descriptive Statistical Analysis}

A descriptive statistical analysis was conducted on the overall distribution of the sample background from four aspects: gender, education level, seniority and position (Table 1).

\subsection{Single-Layer Regression Analysis Results}

\subsubsection{Paternalistic Leaders' Regression Analysis of Psychological Contract Perception}

As showed in the Figure 1, we should discuss about the relationship between 


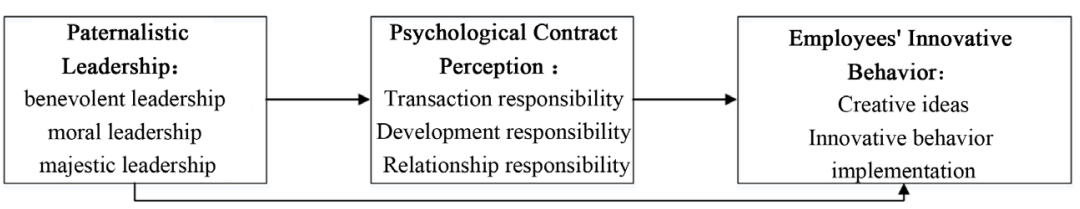

Figure 1. The conceptual model.

Table 1. The descriptive statistical analysis.

\begin{tabular}{cccc}
\hline & & the number & Percentage \\
\hline \multirow{3}{*}{ Gender } & male & 106 & $54.08 \%$ \\
& female & 90 & $45.92 \%$ \\
Weniority & Within one year & 53 & $27.04 \%$ \\
& $1-3$ years (including 1 year) & 62 & $31.63 \%$ \\
& $3-5$ years (including 3 years) & 25 & $12.76 \%$ \\
Education level & More than 5 years & 56 & $28.57 \%$ \\
& junior college & 11 & $5.61 \%$ \\
& undergraduate & 113 & $57.65 \%$ \\
& Master's degree or above & 72 & $36.73 \%$ \\
Position & General staff & 105 & $53.57 \%$ \\
& Basic management & 48 & $24.49 \%$ \\
& Middle management & 38 & $19.39 \%$ \\
& Top management & 5 & $2.55 \%$ \\
\hline
\end{tabular}

paternalistic leader and psychological contract perception. From the correlation analysis results (Table 2), we can find that there is a significant correlation between the dimensions of paternalistic leadership and psychological contractual perception, which indicates that there is a correlation between two, and whether or not there is a causal relationship must be detected through regression analysis.

The three dimensions of paternalistic leadership can explain $51.9 \%$ of the psychological contractual perception. From the standardization coefficient and the level of significance, it can be seen that both benevolent leaders and moral leaders have a significant positive influence on the psychological contractual perception. Therefore, $\mathrm{H} 1, \mathrm{H} 2$, and $\mathrm{H} 3$ are established.

\subsubsection{Regression Analysis of Psychological Contract Perception to Innovation Behavior}

As showed in the Figure 1, we should discuss about the relationship between innovation behavior and psychological contract perception. There is a positive correlation between psychological contract perception and employees' innovation behavior, and the causality is tested by regression (Table 3 ).

The psychological contractual perception can explain $27.6 \%$ employees' conception of innovation, and it can be seen from the significant level of the 
Table 2. The result of the regression between paternalistic leader and psychological contract perception.

\begin{tabular}{cccc}
\hline & regression coefficients & correlation coefficient & reliability coefficient \\
\hline & psychological contract perception & \\
\hline benevolent leadership & $0.352^{* *}$ & $0.635^{* *}$ & 0.869 \\
moral leadership & $0.441^{* *}$ & $0.668^{* *}$ & 0.863 \\
majestic leadership & $-0.012^{*}$ & $-0.12^{*}$ & 0.634 \\
$R^{2}$ & 0.519 & & \\
F & $76.704^{* *}$ & \\
\hline
\end{tabular}

**. Significantly related on the .01 level (both sides). ${ }^{\star}$. Significant correlation at 0.05 level (bilateral).

Table 3. The result of the regression between innovation behavior and psychological contract perception.

\begin{tabular}{|c|c|c|c|c|c|}
\hline & \multicolumn{2}{|c|}{ regression coefficients } & \multicolumn{2}{|c|}{ correlation coefficient } & \multirow[t]{2}{*}{ reliability coefficient } \\
\hline & \multicolumn{4}{|c|}{ employees' innovative behavior } & \\
\hline & $\begin{array}{l}\text { Creative } \\
\text { ideas }\end{array}$ & $\begin{array}{c}\text { Innovative behavior } \\
\text { implementation }\end{array}$ & $\begin{array}{l}\text { Creative } \\
\text { ideas }\end{array}$ & $\begin{array}{c}\text { Innovative behavior } \\
\text { implementation }\end{array}$ & \\
\hline $\begin{array}{l}\text { Transaction } \\
\text { responsibility }\end{array}$ & $0.395^{\star *}$ & $0.118^{\star}$ & $0.434^{\star *}$ & $0.377^{\star *}$ & 0.819 \\
\hline $\begin{array}{l}\text { Development } \\
\text { responsibility }\end{array}$ & $0.347^{\star *}$ & $0.364^{\star *}$ & $0.514^{\star *}$ & $0.499^{\star *}$ & 0.909 \\
\hline $\begin{array}{l}\text { Relationship } \\
\text { responsibility }\end{array}$ & $0.220^{*}$ & $0.183^{\star}$ & $0.469^{\star *}$ & $0.465^{\star *}$ & 0.934 \\
\hline$R^{2}$ & 0.276 & 0.260 & & & \\
\hline $\mathrm{F}$ & $27.110^{* *}$ & $24.965^{\star *}$ & & & \\
\hline
\end{tabular}

standardization coefficient $\beta$ that the psychological contract perception has a significant positive effect on employees' innovative ideas. Psychological contract perception can explain $26 \%$ of employees' implementation of innovation behavior. It can be known from the standardization coefficient $\beta$ and significant level that psychological contract perception has a significant positive effect on the implementation of employee innovation behavior. Therefore, the $\mathrm{H7}$ is established.

\subsubsection{Paternalistic Leadership's Regression Analysis of Innovative Behavior}

As showed in the Figure 1, we should discuss about the relationship between innovation behavior and paternalistic leadership. With paternalistic leadership as an independent variable, two dimensions of employees' innovative behavior (employees' creative ideas, implementation of innovative behaviors) were used as the dependent variables, and regression analysis was conducted (Table 4).

The three dimensions of paternalistic leadership can explain $28.7 \%$ of the employee's creative ideas and can explain $32.7 \%$ of the implementation of innovation behavior. From the standardization coefficient $\beta$ and the significant level, it 
Table 4. The result of the regression between innovation behavior and paternalistic leadership.

\begin{tabular}{|c|c|c|c|c|}
\hline & \multicolumn{4}{|c|}{ employees' innovative behavior } \\
\hline & \multicolumn{2}{|c|}{ regression coefficients } & \multicolumn{2}{|c|}{ correlation coefficient } \\
\hline & Creative ideas & $\begin{array}{c}\text { Innovative behavior } \\
\text { implementation }\end{array}$ & Creative ideas & $\begin{array}{c}\text { Innovative behavior } \\
\text { implementation }\end{array}$ \\
\hline benevolent leadership & $0.199^{\star}$ & $0.309^{\star *}$ & $0.429^{\star *}$ & $0.501^{\star *}$ \\
\hline moral leadership & $0.389^{* *}$ & $0.328^{\star *}$ & $0.497^{\star *}$ & $0.507^{\star *}$ \\
\hline majestic leadership & $-0.139^{*}$ & $-0.132^{*}$ & $-0.259^{*}$ & $-0.345^{*}$ \\
\hline $\mathrm{F}$ & $28.579^{\star *}$ & $34.545^{\star *}$ & & \\
\hline$R^{2}$ & 0.287 & 0.327 & & \\
\hline
\end{tabular}

can be seen that benevolent leadership and moral leadership have a significant positive impact on employees' innovative behavior, and majestic leadership has a negative impact on employees' innovative behavior. Therefore, the $\mathrm{H} 4, \mathrm{H} 5$ and H6 is established.

\section{Conclusion}

The paternalistic leaders of the moral leadership and benevolent leadership are positive correlations in the perception of transaction responsibility, development and achievement perception, and perception of relationship responsibility. The majestic leadership is negative relationship with transactional responsibility perception, development and achievement perception, and relationship responsibility perception. The moral leadership and charitable leadership each has a positive effect on employees' innovation, but majestic leadership has a negative impact. Psychological contract perception has a positive effect on employees' innovative behavior.

\section{References}

[1] Kleysen, R.F. and Street, C.T. (2001) Toward a Multi-Dimensional Measure of Individual Innovative Behavior. Journal of Intellectual Capital, 2, 284-296. https://doi.org/10.1108/EUM0000000005660

[2] Rousseau, D.M. and Mclean, P.J. (1993) The Contracts of Individuals and Organizations. Research in Organizational Behavior, 15, 1-43.

[3] Zhang, X. (2014) Multi-Level Influences of Servant and Paternalistic Leadership on Innovative Behavior: The Mediating Effect of Psychological Empowerment. China Management Studies, 12, 1-45.

[4] May, R. and Guest, D. (2010) The Psychological Contract. Research in Organization Behavior,China.

[5] Ashford, S.J. and Tsui, A.S. (1991) Self-Regulation for Managerial Effectiveness: The Role of Active Feedback Seeking. Academy of Management Journal, 34, 251-280. https://doi.org/10.2307/256442

[6] Hakimian, F., et al. (2014) The Role of Paternalistic Leadership on Fostering Employees' Innovative Behavior: Moderating Effects of Job Insecurity. International 
Journal of Research in Business \& Technology, 4, No. 2.

[7] Hui, L.I., et al. (2014) The Impact of Leadership on Employee Innovation Behavior in the Context of China-The Perspective of Paternalistic Leadership Ternary Theory. Chinese Journal of Management, 12, 1-45.

[8] Tian, Q. and Sanchez, J.I. (2017) Does Paternalistic Leadership Promote Innovative Behavior? The Interaction between Authoritarianism and Benevolence. Journal of Applied Social Psychology, 47, No. 5. https://doi.org/10.1111/jasp.12431

[9] Williams, L.J. and Anderson, S.E. (1991) Job Satisfaction and Organizational Commitment as Predictors of Organizational Citizenship and In-Role Behaviors. Journal of Management, 17, 601-617. https://doi.org/10.1177/014920639101700305

[10] Turnley, W.H., et al. (2003) The Impact of Psychological Contract Fulfillment on the Performance of In-Role and Organizational Citizenship Behaviors. Journal of Management, 29, 187-206. https://doi.org/10.1177/014920630302900204 


\section{Appendix}

Table A1. The questionnaire of Paternalistic Leadership.

\begin{tabular}{|c|c|c|}
\hline & question & $1-5$ \\
\hline \multirow{6}{*}{$\begin{array}{l}\text { benevolence } \\
\text { leadership }\end{array}$} & The leader is concerned about the personal life of the employees. & \\
\hline & Leaders often ask questions about their employees. & \\
\hline & Leaders always help employees when they need help. & \\
\hline & $\begin{array}{l}\text { Leaders will analyze every employee and meet their needs when they } \\
\text { need help. }\end{array}$ & \\
\hline & The leader has a timely understanding of my life and family situation. & \\
\hline & The leader will not embarrassed me in front of my colleagues & \\
\hline \multirow{4}{*}{ moral leadership } & The leader is just & \\
\hline & Leaders treat employees sincerely and truthfully. & \\
\hline & Leaders don't pull strings because of their own interests. & \\
\hline & Leaders lead by example in their work. & \\
\hline \multirow{6}{*}{$\begin{array}{l}\text { Authoritarianism } \\
\text { leadership }\end{array}$} & $\begin{array}{l}\text { The leader will not disclose the relevant information } \\
\text { of the enterprise to me. }\end{array}$ & \\
\hline & All business affairs are controlled by the leader. & \\
\hline & All the business affairs of the enterprise are controlled by the leader. & \\
\hline & When working with leaders, they feel the pressure. & \\
\hline & When the task is not complete, the leader will scold me directly. & \\
\hline & The leader will let the staff work according to his will. & \\
\hline
\end{tabular}

Table A2. The questionnaire of Psychological Contract Perception.

\begin{tabular}{|c|c|c|}
\hline & Questions & $1-5$ \\
\hline \multirow{5}{*}{$\begin{array}{l}\text { Transaction } \\
\text { responsibility }\end{array}$} & Provide corresponding welfare benefits. & \\
\hline & The company provides me with competitive compensation. & \\
\hline & Offer relatively stable job opportunities. & \\
\hline & Pay salary and bonus according to my performance and performance. & \\
\hline & Provide a comfortable and safe working environment. & \\
\hline \multirow{7}{*}{$\begin{array}{l}\text { Development } \\
\text { responsibility }\end{array}$} & Provide up-to-date knowledge learning and skills training opportunities & \\
\hline & Internal promotion and development opportunities & \\
\hline & I have autonomy in my work & \\
\hline & $\begin{array}{l}\text { Offer opportunities to participate in company decisions and } \\
\text { offer advice. }\end{array}$ & \\
\hline & The jobs offered will give full play to my talents. & \\
\hline & The arrangement is challenging for my work. & \\
\hline & Help me with my career planning. & \\
\hline \multirow{4}{*}{$\begin{array}{l}\text { Relationship } \\
\text { responsibility }\end{array}$} & My superior can communicate with me honestly & \\
\hline & Give me full respect and trust. & \\
\hline & Be fair to me. & \\
\hline & Affirm my contribution and achievement to the unit. & \\
\hline
\end{tabular}


Table A3. The questionnaire of innovative behavior.

\begin{tabular}{|c|c|c|}
\hline & Questions & $\begin{array}{c}1-5 \\
\text { points }\end{array}$ \\
\hline \multirow{6}{*}{ Creative ideas } & I will focus on issues that are not common in my work & \\
\hline & $\begin{array}{l}\text { I will look for opportunities to improve the organization, department, } \\
\text { workflow, or service. }\end{array}$ & \\
\hline & $\begin{array}{l}\text { I will come up with new ideas or new solutions to the problems that } \\
\text { arise in my work. }\end{array}$ & \\
\hline & $\begin{array}{l}\text { I will look at the problems in my work from different perspectives to } \\
\text { gain more insight. }\end{array}$ & \\
\hline & I will try out new ideas or new solutions. & \\
\hline & $\begin{array}{l}\text { I will evaluate the strengths and weaknesses of new ideas and choose } \\
\text { the best solution. }\end{array}$ & \\
\hline \multirow{6}{*}{$\begin{array}{c}\text { Innovative } \\
\text { behavior } \\
\text { implementation }\end{array}$} & I will try to convince others of the importance of new ideas. & \\
\hline & $\begin{array}{l}\text { I will take the initiative to promote the new idea and give it a chance to } \\
\text { be implemented. }\end{array}$ & \\
\hline & I would risk it to support new ideas or methods. & \\
\hline & I'm going to do something that might benefit the organization. & \\
\hline & $\begin{array}{l}\text { When applying new methods to work processes, I try to fix the bugs that } \\
\text { arise from the new approach. }\end{array}$ & \\
\hline & $\begin{array}{l}\text { I will apply new ideas and methods to daily work to improve } \\
\text { workflow, technology, products, or services. }\end{array}$ & \\
\hline
\end{tabular}

